\title{
Maternal and foetal outcome in elective versus emergency caesarean sections
}

\author{
Amit A. Gurunule, Himangi S. Warke*
}

Department of Obstetrics and Gynecology, Seth Gordhandas Sunderdas Medical College and King Edward Memorial Hospital, Parel, Mumbai, India

Received: 20 February 2017

Accepted: 25 February 2017

*Correspondence:

Dr. Himangi S. Warke,

E-mail: himangiwarke@kem.edu

Copyright: ( ) the author(s), publisher and licensee Medip Academy. This is an open-access article distributed under the terms of the Creative Commons Attribution Non-Commercial License, which permits unrestricted non-commercial use, distribution, and reproduction in any medium, provided the original work is properly cited.

\section{ABSTRACT}

Background: Caesarean delivery is defined as the birth of the foetus through an incision in the abdominal wall (i.e. laparotomy) and the uterine wall (hysterotomy). The purpose was to analyze the maternal and foetal outcome in elective versus emergency caesarean sections retrospectively in a tertiary care centre and to analyze the indications of elective versus emergency caesarean sections.

Methods: A retrospective observational study of the cases undergoing caesarean sections in KEM hospital, Mumbai, India was carried out during the period of September 2013 to September 2015. Maternal and foetal outcome was studied. The data was collected and analyzed from the maternal medical records. The neonatology records were also examined.

Results: Out of the 600 selected patients, 300 patients in each group of elective and emergency caesarean section were studied. The usual indications of emergency caesarean sections were foetal distress, followed by meconium stained amniotic fluid (MSAF) and cephalopelvic disproportion (CPD). The most frequent indicator for elective lower segment caesarean section (LSCS) was patient with previous LSCS not willing for vaginal birth, followed by breech presentation and previous multiple LSCS. There was a significant difference seen in the occurrence of fever, urinary tract infections and wound infections in the two groups. These were more common in the emergency caesarean section group. Significant difference was also seen in the incidence of postpartum haemorrhage in the two groups, which was more in the elective caesarean section group.

Conclusions: The maternal morbidity, intra operative and postoperative complications were more in the emergency LSCS group as compared to patients who underwent elective LSCS.

Keywords: Emergency LSCS, Elective LSCS, Maternal and foetal outcome

\section{INTRODUCTION}

Caesarean delivery is defined as the birth of the foetus through an incision in the abdominal wall (i.e. laparotomy) and the uterine wall (hysterotomy). ${ }^{1}$

Caesarean section is one of the most commonly performed surgical procedures in today's obstetric practice, and is associated with a great deal of maternal morbidity.

Previously caesarean section was used to save the life of the mother and with associated mortality of 50-70\%. With the immense advances in anaesthetic services and improved surgical techniques the morbidity and mortality of the procedure has decreased considerably. 
Disadvantages of caesarean section are much more as compared to normal vaginal delivery. This is not only in terms of pain and trauma associated with an abdominal operation, but also because of the complications that may be associated with it. ${ }^{1,2}$ It is also expensive in terms of cost of the procedure and duration of postpartum stay in the hospital that is required. ${ }^{3}$

The nature of the caesarean section performed as elective or emergency is predicted depending on the indication of the caesarean section. ${ }^{4}$ The complications arising from elective caesarean sections are much less as compared to emergency caesarean sections. ${ }^{5}$

However, in spite of all the measures taken to electively deliver the pregnancy by caesarean section, many times emergency caesarean section may have to be resorted to for foetal or maternal salvage, though there are many problems associated with it. The present study was therefore undertaken to study the maternal and foetal outcome in patients delivered by elective caesarean section as compared to those delivered by emergency caesarean sections.

\section{METHODS}

A retrospective comparative study was conducted in the department of obstetrics and gynaecology at a tertiary referral centre between September 2013 and September 2015. Patients with singleton pregnancy irrespective of gestation age undergoing caesarean sections at our tertiary referral centre were enrolled. The study commenced after the approval of institutional ethics committee. In this study two groups of pregnant females were studied.

Group 1: Women undergoing elective caesarean sections. Group 2: Women undergoing emergency caesarean sections.

Maternal and perinatal outcome of 300 pregnant women in each group was studied. Waiver of consent was taken as these were retrospective cases. Patients fulfilling inclusion criteria were enrolled in the study. Complete history of the patient along with relevant investigations was reviewed from the medical records. No special investigations were done for the purpose of the study. Approximately 150-200 patients undergo elective caesarean sections and 2000-2500 patients undergo emergency caesarean sections in the age group 18 years or more per year at our tertiary referral centre. Considering the exclusion criteria of the study, the sample size chosen was 300 cases in each group.

\section{Inclusion criteria}

All pregnant women with singleton pregnancy, irrespective of parity status, with or without pregnancy associated complications, with or without medical or surgical high risk, with any gestational age undergoing lower segment caesarean sections at our tertiary referral centre, irrespective of their registration status (patients who are referred at the time of delivery and those registered in the antenatal period) were included.

\section{Exclusion criteria}

Multiple pregnancies were excluded from the study.

The following parameters were studied:

Maternal data was collected in terms of:

- $\quad$ Mode of previous delivery.

- Indication for caesarean sections.

- Intraoperative and postoperative complications.

Neonatal data was collected in terms of foetal outcome and perinatal complications.

\section{Maternal and perinatal outcome}

Indications for caesarean section and maternal and foetal outcome in women who underwent elective and emergency caesarean sections were studied and the following parameters was assessed and compared in the two groups.

\section{Indications for caesarean sections}

- Repeat caesarean section.

- Malpresentation.

- Antepartum haemorrhage.

- Cephalopelvic disproportion.

- Foetal distress.

- Pre-eclampsia.

- Eclampsia.

- Obstructed labour.

- Non-progress of labour.

\section{Obstetric complications}

\section{Maternal complications}

- Intraoperative maternal complications:
a. Haemorrhage.
b. Extension of uterine incision/tear.
c. Bladder injury.
d. Caesarean hysterectomy.

- Postoperative maternal complications:
a. Wound infection.
b. Fever.
c. UTI.
d. DIC.
e. Maternal death.

\section{Foetal complications}

- Respiratory distress. 
- Liquor aspiration.

- Soft tissue injury.

- Perinatal death.

\section{Perinatal outcome}

- Born alive.

- Fresh still birth.

- Macerated dead baby.

- Early neonatal death.

\section{Statistical analysis}

After data collection, data entry was done in excel sheet.
Data analysis was done with the help of SPSS Software version 23. Data was analysed with the help of frequency and percentage table. Association among study groups was assessed with the help of Chi-square test, and $\mathrm{P}$ value less than 0.05 was taken as statistically significant.

\section{RESULTS}

In this study pregnant women who had undergone elective caesarean sections were compared with women who had undergone emergency caesarean sections and maternal and perinatal outcome of 300 pregnant women in each group was studied.

Table 1: Indication of caesarean section and the type of LSCS.

\begin{tabular}{|lllll|}
\hline Indication of LSCS & Type of LSCS & & Total & P-value \\
\hline Antepartum haemorrhage (APH) & Elective $(\mathbf{n = 3 0 0})$ & Emergency $(\mathbf{n}=\mathbf{3 0 0})$ & $37(6.2 \%)$ & 0.12 \\
\hline Breech presentation & $23(7.6 \%)$ & $14(4.7 \%)$ & $77(12.8 \%)$ & 0.00 \\
\hline Cord prolapse & $58(19.3 \%)$ & $19(6.3 \%)$ & $3(0.5 \%)$ & 0.24 \\
\hline Cephalopelvic disproportion (CPD) & $0(0.0 \%)$ & $3(1.0 \%)$ & $85(14.1 \%)$ & 0.29 \\
\hline Foetal distress & $47(15.6 \%)$ & $38(12.7 \%)$ & $109(18.1 \%)$ & 0.00 \\
\hline Malpresentation & $12(4.0 \%)$ & $97(32.3 \%)$ & $9(1.5 \%)$ & 1.00 \\
\hline Meconium stained amniotic fluid (MSAF) & $4(1.3 \%)$ & $5(1.7 \%)$ & $60(10.0 \%)$ & 0.00 \\
\hline Non-progress of labour & $0(0.0 \%)$ & $60(20.0 \%)$ & $22(3.7 \%)$ & 0.00 \\
\hline Others & $0(0.0 \%)$ & $22(7.3 \%)$ & $29(4.8 \%)$ & 0.18 \\
\hline Pre-eclampsia & $18(6.0 \%)$ & $11(3.7 \%)$ & $9(1.5 \%)$ & 0.50 \\
\hline Previous LSCS not willing for vaginal birth & $6(2.0 \%)$ & $3(1.0 \%)$ & $98(16.5 \%)$ & 0.00 \\
\hline Previous multiple LSCS $(\geq 2$ LSCS) & $79(26.6 \%)$ & $19(6.3 \%)$ & $62(10.3 \%)$ & 0.00 \\
\hline P-O.000 & $53(17.6 \%)$ & $9(3.0 \%)$ & & \\
\hline
\end{tabular}

$\mathrm{P}=0.000$.

Foetal distress was the most common indication in the emergency LSCS group (32.3\%), followed by meconium stained amniotic fluid (20\%) and CPD (12.7\%).

Table 2: Obstetric complications and the type of LSCS.

\begin{tabular}{|llll|}
\hline $\begin{array}{l}\text { Obstetric } \\
\text { complications }\end{array}$ & $\begin{array}{l}\text { Type of LSCS } \\
\text { Elective } \\
(\mathbf{n = 3 0 0 )}\end{array}$ & $\begin{array}{l}\text { Emergency } \\
(\mathbf{n = 3 0 0})\end{array}$ & $\begin{array}{l}\text { P- } \\
\text { value }\end{array}$ \\
\hline $\begin{array}{l}\text { Obstetric } \\
\text { hysterectomy }\end{array}$ & $3(1 \%)$ & $0(0.0 \%)$ & 0.24 \\
\hline $\begin{array}{l}\text { Uterine } \\
\text { extension }\end{array}$ & $1(0.3 \%)$ & $5(1.7 \%)$ & 0.21 \\
\hline
\end{tabular}

The most common indication for elective LSCS was previous LSCS not willing for vaginal birth in 79 (26.6\%), followed by breech presentation (19.3\%) and previous multiple LSCS (17.6\%). The statistical association between indication and type of LSCS was found to be significant in foetal distress, breech presentation, MSAF, non-progress of labour, previous LSCS not willing for vaginal birth and previous multiple LSCS with $\mathrm{P}<0.05$.

Previous LSCS not willing for vaginal birth (26.6\%) breech $(19.3 \%), \geq 2 \operatorname{LSCS}(17.6 \%)$ were the common indications in the elective LSCS group. Due to these reasons, it was seen that in our study the incidence of LSCS was more in multigravidas $(77.4 \%)$ as compared to primigravidas $(22.6 \%)$. In primigravidas the common indications were foetal distress (32.3\%), MSAF (20.0\%) and non-progress of labour $(7.3 \%)$ that lead more number of primigravidas undergoing emergency LSCS (Table 1).

There was no significant association between the type of LSCS performed and the obstetric complications that occurred $(\mathrm{P}=0.059)$. Uterine extension occurred to be the most common obstetric complication seen in $5(1.7 \%)$ patients in emergency LSCS group. Among these, 4 patients had undergone LSCS for deep transverse arrest and baby delivery at LSCS was difficult. Obstetric hysterectomy had to be performed in 3 patients in the 
elective LSCS group. Of these two patients had undergone LSCS for placenta previa and had adherent placenta and in one patient obstetric hysterectomy had to be done for postpartum haemorrhage (Table 2).

Post-operative maternal morbidity had a statistical association with the type of LSCS with respect to fever and urinary tract infection with $\mathrm{P}<0.05$, while there was no statistical association in morbidity related to wound infection and maternal mortality, $\mathrm{P}>0.05$. Post-operative morbidity was more marked in the patients undergoing emergency LSCS as compared to those undergoing elective LSCS (Table 3). No statistical association was found between foetal outcome and type of LSCS, $\mathrm{P}=0.172$. This could be due to proper antenatal care and availability of skilful neonatologist at the time of caesarean section and improved neonatal intensive care unit (NICU) care. This may have decreased the morbidity and mortality in babies born. However, the table indicates greater number of adverse foetal outcome in the emergency LSCS group (Table 4).

Table 3: Post-operative maternal complications and the type of LSCS.

\begin{tabular}{|lllll|}
\hline Post-operative maternal complications & Type of LSCS & & Total & P-value \\
\hline Fever & Elective $(\mathbf{n = 3 0 0})$ & Emergency $(\mathbf{n = 3 0 0})$ & $26(4.3 \%)$ & 0.025 \\
\hline Maternal mortality & $7(2.3 \%)$ & $19(6.3 \%)$ & $1(0.2 \%)$ & 1.00 \\
\hline UTI & $0(0.0 \%)$ & $1(0.3 \%)$ & $13(2.2 \%)$ & 0.02 \\
\hline Wound infection & $2(0.7 \%)$ & $11(3.7 \%)$ & $15(2.5 \%)$ & 0.6 \\
\hline
\end{tabular}

$\mathrm{P}=0.006$.

Table 4: Foetal outcome and the type of LSCS.

\begin{tabular}{|lllll|}
\hline Foetal outcome & Type of LSCS & & Total & P-value \\
\hline Fresh still births (FSB) & Elective $(\mathbf{n = 3 0 0})$ & Emergency (n=300) & $7(1.2 \%)$ & 0.12 \\
\hline Live births & $1(0.3 \%)$ & $6(2.0 \%)$ & $578(96.3 \%)$ & 0.12 \\
\hline Macerated still births (MSB) & $293(97.7 \%)$ & $285(95.0 \%)$ & $1(0.2 \%)$ & 1 \\
\hline Neonatal deaths (NND) & $0(0.0 \%)$ & $1(0.3 \%)$ & $14(2.3 \%)$ & 0.78 \\
\hline
\end{tabular}

$\mathrm{P}=0.172$.

Table 5: Perinatal foetal complication and the type of LSCS.

\begin{tabular}{|llll|}
\hline Perinatal complications & Type of LSCS & & Emergency $(\mathbf{n = 3 0 0 )}$ \\
\hline Meconium aspiration & Elective $(\mathbf{n = 3 0 0})$ & P value \\
\hline Meconium aspiration with RDS & $0(0.0 \%)$ & $1(0.3 \%)$ & 1.0 \\
\hline Respiratory distress & $0(0.0 \%)$ & $1(0.3 \%)$ & 1.0 \\
\hline Scalp injury & $12(4.0 \%)$ & $21(7.0 \%)$ & 0.10 \\
\hline
\end{tabular}

$\mathrm{P}=0.340$.

There was no statistical association between perinatal complications and the type of LSCS performed $(\mathrm{P}=0.340)$. However, the numbers denote greater chances of perinatal complications in emergency LSCS group (Table 5).

\section{DISCUSSION}

In this retrospective study from September 2013 to September 2015 we have compared maternal and foetal outcome in elective versus emergency LSCS in 600 cases, 300 elective LSCS and 300 emergency LSCS done at KEM hospital Mumbai, Maharashtra, India. The caesarean section rate in our institute during the study period was $33 \%$. Results have been analysed and compared with other studies from India and other countries.

In the study conducted by Lulu et al elective LSCS done in view of previous LSCS, non-progress of labour, breech, foetal distress and antepartum haemorrhage (APH) were $69.5 \%, 0 \%, 14.6 \%, 0.4 \%, 2.8 \%$ respectively and the emergency LSCS were $0 \%, 41.5 \%, 16.0 \%$, $15.9 \%, 9.3 \%$ respectively. ${ }^{6}$

In the study conducted by Vesna E-G et al elective LSCS done in view of previous LSCS, non-progress of labour, breech, foetal distress and APH were 48.32\%, 0\%, 
$33.7 \%, 0 \%$ respectively and the emergency LSCS were $0 \%, 7.45 \%, 12.76 \%, 7.45 \%$ respectively. $^{7}$

In the study conducted by Najam R et al LSCS done in view of previous LSCS, non-progress of labour, breech, foetal distress and APH electively was $42.5 \%, 22.2 \%$, $45.5 \%, 23.07 \%, 28.5 \%$ respectively and that of emergency LSCS was $57.5 \%, 77.7 \%, 54.5 \%, 76.9 \%$, $71.4 \%$ respectively. ${ }^{8}$

In present study elective LSCS done in view of previous LSCS, non-progress of labour, breech, foetal distress and APH were $44.2 \%, 0 \%, 19.3 \%, 4.0 \%, 7.6 \%$ respectively and emergency LSCS done for the same indications were $9.3 \%, 7.3 \%, 6.3 \%, 32.3 \%, 4.7 \%$ respectively.
The incidence of LSCS done in view of previous LSCS in present study is similar to the other studies except the study by Najam R et al. ${ }^{8}$

The incidence of LSCS done in view of non-progress of labour was similar to other studies.

The incidence of LSCS done in view of breech presentation is similar to the study by Vesna EG et al, however, it differs from studies by Lulu et al and Najam $\mathrm{R}$ study where the incidence of LSCS done for breech is more in the emergency LSCS group. ${ }^{6-8}$

The incidence of LSCS done in view of foetal distress is similar to the other studies in both the groups.

Table 6: Indications for caesarean section and type of LSCS.

\begin{tabular}{|c|c|c|c|c|c|c|}
\hline Author & Previous CS & $\begin{array}{l}\text { Non-progress } \\
\text { of labour }\end{array}$ & Breech & Foetal distress & APH & Others \\
\hline $\begin{array}{l}\text { Lulu et } \\
\mathrm{al}^{6}\end{array}$ & $\begin{array}{l}\text { Elective-367 } \\
(69.5 \%) \\
\text { Emergency-0 }\end{array}$ & $\begin{array}{l}\text { Elective-0 } \\
\text { Emergency- } \\
373(41.5 \%)\end{array}$ & $\begin{array}{l}\text { Elective-77 } \\
(14.6 \%) \\
\text { Emergency-144 } \\
(16.0 \%)\end{array}$ & $\begin{array}{l}\text { Elective-2 }(0.4 \%) \\
\text { Emergency-143 } \\
(15.9 \%)\end{array}$ & $\begin{array}{l}\text { Elective-15 } \\
(2.8 \%) \\
\text { Emergency-83 } \\
(9.3 \%)\end{array}$ & $\begin{array}{l}\text { Elective-58 } \\
\text { Emergency- } \\
130\end{array}$ \\
\hline 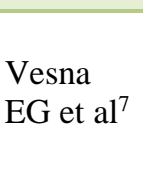 & $\begin{array}{l}\text { Elective-43 } \\
(48.32 \%) \\
\text { Emergency- } 0\end{array}$ & $\begin{array}{l}\text { Elective-0 } \\
\text { Emergency- } 7 \\
(7.45)\end{array}$ & $\begin{array}{l}\text { Elective-30 } \\
(33.7 \%) \\
\text { Emergency- } 12 \\
(12.76 \%)\end{array}$ & $\begin{array}{l}\text { Elective- } 0 \\
\text { Emergency- } 7 \\
(7.45 \%)\end{array}$ & & \\
\hline $\begin{array}{l}\text { Najam R } \\
\text { et } \text { al }^{8}\end{array}$ & $\begin{array}{l}\text { Elective-17 } \\
(42.5 \%) \\
\text { Emergency-23 } \\
(57.5 \%)\end{array}$ & $\begin{array}{l}\text { Elective-4 } \\
(22.2 \%) \\
\text { Emergency-14 } \\
(77.7 \%)\end{array}$ & $\begin{array}{l}\text { Elective- } 10 \\
(45.5 \%) \\
\text { Emergency- } 12 \\
(54.5 \%)\end{array}$ & $\begin{array}{l}\text { Elective- } 3 \\
(23.07 \%) \\
\text { Emergency- } 10 \\
(76.9 \%)\end{array}$ & $\begin{array}{l}\text { Elective- } 6 \\
(28.5 \%) \\
\text { Emergency- } \\
15(71.4 \%)\end{array}$ & $\begin{array}{l}\text { Elective- } 7 \\
\text { Emergency- } \\
54\end{array}$ \\
\hline $\begin{array}{l}\text { Present } \\
\text { study }\end{array}$ & $\begin{array}{l}\text { Elective-133 } \\
(44.2 \%) \\
\text { Emergency- } 28 \\
(9.3 \%)\end{array}$ & $\begin{array}{l}\text { Elective- } 0 \\
\text { Emergency- } \\
22(7.3 \%)\end{array}$ & $\begin{array}{l}\text { Elective- } 58 \\
(19.3 \%) \\
\text { Emergency- } 19 \\
(6.3 \%)\end{array}$ & $\begin{array}{l}\text { Elective- } 12 \\
(4.0 \%) \\
\text { Emergency- } 97 \\
(32.3 \%)\end{array}$ & $\begin{array}{l}\text { Elective- } 23 \\
(7.6 \%) \\
\text { Emergency- } \\
14(4.7 \%)\end{array}$ & $\begin{array}{l}\text { Elective-75 } \\
\text { Emergency- } \\
117\end{array}$ \\
\hline
\end{tabular}

Other indications: (CPD, malpresentation, MSAF, cord prolapse, pre-eclampsia, brow presentation, scar tenderness, anhydramnios, genital warts). Previous caesarean section- (previous LSCS not willing for vaginal birth, previous multiple LSCS), APH (Antepartum haemorrhage)- placenta previa, abruptio placenta.

Table 7: Obstetric complications in elective versus emergency caesarean section.

\begin{tabular}{|lllll|}
\hline Author & Year & Uterine extension & Obstetric hysterectomy & Bladder injury \\
\hline \multirow{2}{*}{ Najam R et al } & \multirow{2}{*}{2013} & Elective- 1 & Elective- 0 & Elective- 0 \\
& \multirow{2}{*}{ Emergency- 5 } & Emergency- 3 & Emergency- 1 \\
\hline \multirow{2}{*}{ Present study } & $2013-2015$ & $\begin{array}{l}\text { Elective-1 } \\
\text { Emergency- 5 }\end{array}$ & $\begin{array}{l}\text { Elective-3 } \\
\text { Emergency- 0 }\end{array}$ & Elective-0 \\
& & & Emergency-0
\end{tabular}

The incidence of LSCS done in view of APH differs from other studies. In present study the incidence of LSCS for APH was more in the elective LSCS group than in the emergency LSCS group. This observation could be due to the diagnosis placenta previa and adherent placenta in the antenatal period and early diagnosis and proper management of patients with pregnancy induced hypertension. This signifies that there is statistical significance between major indications of LSCS and type of LSCS P=0.000 (Table 6).

The number of patients with obstetric complications such as uterine extension, obstetric hysterectomy and bladder injury in elective LSCS were 1, 0 , and 0 respectively, while in emergency LSCS group were 5, 3, and 1 respectively. 
In present study the obstetric complications such as uterine extension, obstetric hysterectomy and bladder injury in the elective LSCS group occurred in 1, 3 and 0 patients respectively, while in the emergency LSCS group they occurred in 5, 0 , and 0 patients respectively. Uterine extension had occurred in 4 patients undergoing emergency LSCS for deep transverse arrest involving difficult baby delivery. All 3 obstetric hysterectomies had to be done in the elective LSCS group, 2 cases were of adherent placenta and one case was of atonic postpartum haemorrhage. In a study by Najam R et al study obstetric hysterectomies had to be performed in the emergency LSCS group. ${ }^{8}$ As ours is a tertiary referral centre, patients with high risk pregnancies e.g. pplacenta previa, adherent placenta etc. are referred during the antenatal period. ( $\mathrm{P}$ value 0.059 ) implies no significant statistical association between obstetrics complications and the type of LSCS performed (Table 7).

Table 8: Post-operative complications in patients with elective and emergency caesarean sections.

\begin{tabular}{|c|c|c|c|c|c|}
\hline Author & Fever & Wound infection & UTI & Nil & Other \\
\hline $\begin{array}{l}\text { Lulu et } \\
\mathrm{al}^{6}\end{array}$ & $\begin{array}{l}\text { Elective-91 (17.2\%) } \\
\text { Emergency-206 } \\
(22.9 \%)\end{array}$ & $\begin{array}{l}\text { Elective-33 } \\
(6.2 \%) \\
\text { Emergency-58 } \\
(6.5 \%)\end{array}$ & $\begin{array}{l}\text { Elective-40 } \\
(7.6 \%) \\
\text { Emergency-139 } \\
(15.5 \%)\end{array}$ & $\begin{array}{l}\text { Elective-340 }(64.4 \%) \\
\text { Emergency-463 } \\
(51.5 \%)\end{array}$ & $\begin{array}{l}\text { Elective-22 } \\
(4.2 \%) \\
\text { Emergency-26 } \\
(2.9 \%)\end{array}$ \\
\hline $\begin{array}{l}\text { Najam R } \\
\text { et } \mathrm{al}^{8}\end{array}$ & $\begin{array}{l}\text { Elective- } 3 \\
\text { Emergency- } 10\end{array}$ & $\begin{array}{l}\text { Elective- } 1 \\
\text { Emergency-20 }\end{array}$ & $\begin{array}{l}\text { Elective- } 0 \\
\text { Emergency- } 4\end{array}$ & $\begin{array}{l}\text { Elective- } 40 \\
\text { Emergency- } 104\end{array}$ & $\begin{array}{l}\text { Elective- } 3 \\
\text { Emergency-11 } \\
\text { Maternal death-1 }\end{array}$ \\
\hline $\begin{array}{l}\text { Present } \\
\text { study }\end{array}$ & $\begin{array}{l}\text { Elective- } 7(2.3 \%) \\
\text { Emergency- } 19 \\
(6.3 \%)\end{array}$ & $\begin{array}{l}\text { Elective- } 6(2.0 \%) \\
\text { Emergency-9 } \\
(3.0 \%)\end{array}$ & $\begin{array}{l}\text { Elective- } 2(0.7 \%) \\
\text { Emergency-11 } \\
(3.7 \%)\end{array}$ & $\begin{array}{l}\text { Elective- } 286(95 \%) \\
\text { Emergency- } 260 \\
(86.7 \%)\end{array}$ & $\begin{array}{l}\text { Maternal } \\
\text { mortality-1 in } \\
\text { Emergency CS }\end{array}$ \\
\hline
\end{tabular}

Table 9: Foetal outcome in elective and emergency caesarean section.

\begin{tabular}{|c|c|c|c|c|c|}
\hline Author & Year & Live births & FSB & MSB & NND \\
\hline Najam $R$ et $a^{8}$ & 2013 & $\begin{array}{l}\text { Elective- } 45 \\
\text { Emergency- } 122\end{array}$ & $\begin{array}{l}\text { Elective- } 1 \\
\text { Emergency- } 3\end{array}$ & $\begin{array}{l}\text { Elective- } 0 \\
\text { Emergency- } 6\end{array}$ & $\begin{array}{l}\text { Elective- } 1 \\
\text { Emergency- } 9\end{array}$ \\
\hline Present study & 2013-2015 & $\begin{array}{l}\text { Elective- } 294 \\
\text { Emergency- } 285\end{array}$ & $\begin{array}{l}\text { Elective- } 1 \\
\text { Emergency- } 6\end{array}$ & $\begin{array}{l}\text { Elective- } 0 \\
\text { Emergency- } 1\end{array}$ & $\begin{array}{l}\text { Elective- } 6 \\
\text { Emergency-8 }\end{array}$ \\
\hline
\end{tabular}

The incidence of post-operative morbidity like fever, wound infection and UTI in a study by Lulu et al was more in the emergency LSCS group being $22.9 \%, 6.5 \%$, $15.5 \%$ respectively. ${ }^{6}$ Najam $\mathrm{R}$ et al also had similar results. ${ }^{8}$ Present study had similar results as compared to other studies in case of post-operative morbidity like fever $(6.3 \%)$, wound infection $(3.0 \%)$ and UTI $(3.7 \%) .1$ maternal mortality occurred in the emergency LSCS group. This patient was a multigravida with one previous LSCS and LSCS was done for complete placenta previa with adherent placenta. The cause of death in this case was sepsis with DIC. In present study (P value 0.006) suggests significant statistical association between postoperative maternal complications and type of LSCS (Table 8).

In the study conducted by Najam $\mathrm{R}$ et al the number of live births were 45, fresh still birth (FSB) one, neonatal death (NND) one and no case of macerated still birth (MSB) in the patients who underwent elective LSCS. ${ }^{8}$ In the patients who underwent emergency LSCS 122 were live births, 3 were FSB and 6 were MSB.Neonatal deaths occurred in 9 babies.
In present study the number of live births, FSB, MSB, and NND in elective LSCS were 294, 1, 0, and 6 respectively whereas in the emergency LSCS group it was $285,6,1$, and 8 respectively. The observations of our study are similar with the other study quoted indicating a poor foetal outcome in the emergency LSCS group as compared to the elective LSCS group. However, present study shows no significant statistical association ( $\mathrm{P}$ value 0.172 ) between the type of LSCS and the foetal outcome. This may due to proper antenatal care, timely intervention and improved and skilful NICU care and availability of trained assistants at the time of surgery (Table 9).

In the study conducted by Najam $\mathrm{R}$ et al the number of cases with respiratory distress were 4 and in only 1 case meconium aspiration occurred in the elective LSCS group. ${ }^{8}$ No case of soft tissue injury was documented in the elective LSCS group. Respiratory distress was seen in 15 cases, meconium aspiration in 8 cases and soft tissue injury in 2 cases were documented in the emergency LSCS group. 
Table 10: Perinatal complications in elective and emergency caesarean section.

\begin{tabular}{|c|c|c|c|c|}
\hline Author & Year & Respiratory distress & Meconium aspiration & Soft tissue injury \\
\hline Najam R et al ${ }^{8}$ & 2013 & $\begin{array}{l}\text { Elective- } 4 \\
\text { Emergency- } 15\end{array}$ & $\begin{array}{l}\text { Elective- } 1 \\
\text { Emergency- } 8\end{array}$ & $\begin{array}{l}\text { Elective- } 0 \\
\text { Emergency- } 2\end{array}$ \\
\hline Present study & 2013-2015 & $\begin{array}{l}\text { Elective- } 12 \\
\text { Emergency-21 }\end{array}$ & $\begin{array}{l}\text { Elective- } 0 \\
\text { Emergency-2 }\end{array}$ & $\begin{array}{l}\text { Elective-0 } \\
\text { Emergency-1 }\end{array}$ \\
\hline
\end{tabular}

In present study there were 12 cases of respiratory distress and no case of meconium aspiration and scalp injury in the elective LSCS group. In patients undergoing emergency LSCS 21 cases of respiratory distress, one case each of meconium aspiration and meconium aspiration with respiratory distress was seen and only a single case of scalp injury was documented in the emergency LSCS group. Respiratory distress is the most common perinatal complication in the babies born by LSCS followed by meconium aspiration and the observations of our study are similar with the other study quoted.

However, there is no significant statistical association between perinatal complications and type of LSCS performed (P value 0.34) (Table 10).

\section{CONCLUSION}

Caesarean section is a safe operation. The proportion of maternal and perinatal complications can be reduced in emergency LSCS by encouraging all patients to visit antenatal care (ANC) clinics regularly, so that patients who are likely candidates for caesarean section can be detected early and posted for elective LSCS. The cases of bleeding placenta previas and other high risk cases could be managed by elective procedures. The cases of abruptio placentae can be reduced if patients had regular ANC visits so that patients with PIH can be detected early and complications of PIH prevented. Everything points to the advantages that can be derived from a planned caesarean section as compared to one that is undertaken as an emergency. Every effort should be made in the ANC clinic to pick up the cases who may land up in difficult labour, for example large babies, small pelvis etc. that may indicate the need of emergency caesarean section. However, this approach may neither increase nor decrease our caesarean section rates. A fully equipped NICU and trained paediatricians should be made available at the tertiary referral institutes where the proportion of emergency LSCS are on rise.

Funding: No funding sources

Conflict of interest: None declared

Ethical approval: The study was approved by the Institutional Ethics Committee

\section{REFERENCES}

1. Cunningham FG, Hanth VC, Strong VD, Kappus SS. Infections' morbidity following cesarean section. Obstet Gynecol. 1978;52:65661.

2. Minkoff HL, Schwarz RH. The rising cesarean rate: can it safely be reversed? Obstet Gynecol. 1980;56:135-43.

3. Yudkin PL, Redman CWG. Cesarean section dissected, 1978-1983. Brit J Obstet Gynecol. 1986;93:135-44.

4. Toffel S, Placek P, Kosary CVS. Cesarean sections rates 1990: an update. Birth. 1992;19:21-2

5. Choate JW, Lund CJ. Emergency cesarean section: an analysis of maternal and fetal results in 177 operations. Am J Obstet Gynecol. 1968;100:703-15

6. Lulu AN, Mohammad HS, Tariq K, Mohammed A, Noori C, Babutunde A. Outcome in elective and emergency caesarean sections. Ann Saudi Med. 1996;16(6);645-9.

7. Vesna EG, Tajana KP, Branimir P. Maternal and fetal outcome in elective versus emergency caesarean section. Coll Antropol. 2006;30(1);113-8.

8. Najam R, Sharma R. Maternal and fetal outcome in elective and emergency caesarean sections. J Adv Res Biol Sci. 2013;5(1);5-9.

Cite this article as: Gurunule AA, Warke HS. Maternal and foetal outcome in elective versus emergency caesarean sections. Int J Reprod Contracept Obstet Gynecol 2017;6:1222-8. 